\title{
Subglottic Hemangioma
}

National Cancer Institute

\section{Source}

National Cancer Institute. Subglottic Hemangioma. NCI Thesaurus. Code C6026.

A hemangioma arising from the subglottic area. 